\title{
Cytotoxic effects of ergone, a compound isolated from Fulviformes fastuosus
}

\author{
Dilusha Fernando ${ }^{1,2,3^{*}}$, Achyut Adhikari $^{4^{*}}$, Chandrika Nanayakkara ${ }^{1}$, E Dilip de Silva $^{3}$, Ravi Wijesundera ${ }^{1}$ \\ and Preethi Soysa ${ }^{2}$
}

\begin{abstract}
Background: Mushrooms inspired the cuisines of many cultures and conventional medicaments for cancer. However, a substantial number of mushroom species are yet unexplored, possessing an unknown chemical, biological and pharmacological profiles. Fulviformes fastuosus is a terrestrial mushroom, which is commonly found in Sri Lankan woodlands. The current study was aimed at isolation and characterization of a potent cytotoxic compound from F. fastuosus and investigating the apoptotic effect induced by the active principle against cancer and normal cell lines.

Methods: Bioactivity guided isolation of active principles from the methanol extract of $F$. fastuosus was performed by a rapid extraction and isolation method using different chromatographic techniques. Potential cytotoxic compound was identified using one and two dimensional nuclear magnetic resonance spectroscopy and mass spectrometry. Isolated compound was screened for in vitro cytotoxicity against Hepatocellular carcinoma (HepG-2), Muscle rhabdomyosarcoma (RD) and Rat Wistar liver normal (CC-1) cell lines using 34, 5-(dimethylthiazol-2-yl) 2-5diphenyl tetrazolium bromide (MTT) cell viability assay. Apoptotic features of cells were observed via microscopic examination and ethidium bromide/acridine orange fluorescent staining.
\end{abstract}

Results: The interpretation of spectral data resulted in the identification of the chemical structure as ergosta-4,6,8 (14),22-tetraen-3-one (ergone). Ergone exhibited promising cytotoxic properties against RD cells with less cytotoxicity effect on CC-1 cells. In addition, ergone also possesses a strong cytotoxic effect against HepG-2 cells showing low toxic level for CC-1 cells. Apoptotic features of treated cells were detected via morphological characterization and ethidium bromide/acridine orange staining.

Conclusion: The present study elaborates the isolation of a potent cytotoxic compound; ergone, from F. fastuosus via a rapid and efficient isolation method. Importantly, ergone has exhibited greater cytotoxic activity against RD cells with high selectivity index compared to cytotoxicity against HepG-2 cells. Ergone can be used in the development of therapeutic strategies for curbing rhabdomyosarcoma.

Keywords: Mushrooms, Fulviformes fastuosus, Isolation method, Ergone, Cytotoxic activity, Rhabdomyosarcoma, Hepatocellular carcinoma

\footnotetext{
*Correspondence: diluarchive@gmail.com; achyutraj05@gmail.com

${ }^{1}$ Department of Plant Sciences, Faculty of Science, University of Colombo,

Colombo 03, Sri Lanka

${ }^{4}$ The Hussain Ebrahim Jamal Research Institute of Chemistry, ICCBS,

University of Karachi, Karachi, Pakistan

Full list of author information is available at the end of the article
} 


\section{Background}

Mushrooms have long been esteemed as edible and medicinal provisions for humankind. From ancient time, substances derived from mushrooms are considered as a boundless source of anticancer agents [1, 2]. Among the prevailing degenerative diseases in the globe, cancer has become the most prevalent devastating human degenerative disease worldwide [3, 4]. In spite of the availability of modern antineoplastic agents, the number of lives taken by this malicious disease increases annually around the globe. The recent advances in cancer therapies have failed in making significant progress in reducing the morbidity caused by cancer $[5,6]$. In this perspective, the use of secondary metabolites derived from natural sources having promising cytotoxic properties in the development of new and more effective anticancer drugs are highly desirable.

Mushrooms provide potent beneficial effects on cancer either directly as antioxidants or through prevention of genetic alterations underlying cancer [7]. The secondary metabolites derived from mushrooms have the potential to play a leading role in the development of anticancer drugs with minimal side effects $[8,9]$. There are approximately 650 species of macrofungi that have been reported to possess antitumor activity [10]. Calvacin was the most commonly used anticancer compound isolated from giant puffball mushrooms [11]. In addition, lentinan, schizophyllan and krestin derived from mushrooms are approved as prescription drugs for the treatment of cancer in Japan [12]. Currently, fungal extracts and isolated fungal fractions are also being used in the traditional medicine for the treatment of cancer as adjuvants to chemotherapy, surgery and radiotherapy $[13,14]$.

Despite the development of anticancer therapeutics using mushrooms, a large proportion of mushroom species in the world still remain scientifically unexplored making this group one of the mostly untapped microbiotic source for novel drug leads in the anticancer pharmaceutical industry [15]. Intriguingly, the mycological potential of tropical island Sri Lanka is attributable to favorable climatic conditions and floral diversity [16, 17]. However, ethnomycological research in Sri Lanka indicates only a rare use of mushrooms as food or internal medicinal provisions by indigenous practitioners in Sri Lanka $[18,19]$. Hence, the current study was aimed at isolation and characterization of a potent cytotoxic compound from Fulviformes fastuosus harvested from the dry zone forest reserves in Sri Lanka. F. fastuosus belongs to the Hymenochaetaceae family, which is commonly found in dry zone woodlands in Sri Lanka. Members of the Hymenochaetaceae family are known to possess strong bioactive properties including antioxidant and anticancer activity which is strongly attributed to polyphenolic substances contained in the mushrooms
[20]. Since the polyphenolic secondary metabolites produced by $F$. fastuosus mushroom exhibit largely diverse structural differences, the isolation and separation of metabolites can be lengthy and tedious [21]. Therefore, the methods of isolating bioactive compounds are generally optimized to a series of rapid, simple and efficient bioactivity guided fractionations [22, 23].

\section{Methods}

\section{Chemicals and equipment}

Methanol, $\mathrm{HCl}$, hexane, chloroform and ethyl acetate were purchased from BDH Chemicals (Poole, England). MTT (3-(4,5-Dimethylthiazol-2-Yl)-2,5-Diphenyltetrazolium Bromide), Ethidium bromide, Cycloheximide, Isoamyl alcohol, and Acridine orange were purchased from Sigma Chemicals Co. (St. Louis, USA). All chemicals used were of analytical grade.

Shimadzu UV 1601 UV visible spectrophotometer (Shimadzu Corporation, Kyoto, Japan) was used to measure the absorbance. Rotary evaporator (BUCHI Rota vapor R-200) was used to dry the extracts of F. fastuosus. Thin layer chromatography was carried out by using pre coated silica gel $60 \mathrm{~F}{ }_{254}(20 \times 20) \mathrm{cm}^{2}$ Aluminum backed commercial grade sheets. Chromatograms were visualized using UV radiator with 9815 series lamp (254-364 lambda). Nuclear magnetic resonance (NMR) spectra were recorded on a Bruker avance AV- $600 \mathrm{MHz}$ spectrometer with a $5 \mathrm{~mm}$ cryoprobe.

Cells were incubated at $37{ }^{\circ} \mathrm{C}$ in a humidified $\mathrm{CO}_{2}$ incubator (SHEL LAB/Sheldon manufacturing Inc. Cornelius, OR 97113, USA). Olympus (1X70-S1F2) inverted fluorescence microscope (Olympus Optical Co. Ltd. Japan) was used for the observation of cells and images were captured using digital camera (MDC 200, USB 2.0, $2 \mathrm{M}$ pixels $\mathrm{CCD}$ chip) connected to the microscope. Deionized water from LABCONCO (waterproplus) UV ultra-filtered water system (LABCONCO Corporation, Kansas city, Missouri 64132-2696) or distilled water was used in all experiments.

\section{Fungal material}

The specimen of $F$. fastuosus was collected from the dry zone forest reserves of Dambulla, Sigiriya, and Minneriya in Sri Lanka and transported to the laboratory with proper ventilation. The identity of the specimen was authenticated by a botanist of Department of Plant Science, Faculty of Science, University of Colombo, and molecular studies confirmed the identity of the species (Genbank Accession No.: KP757737). Voucher specimens were deposited at the same Institute (UOC:DAMIA: D27b).

Large scale extraction of fruiting bodies of $F$. fastuosus Mature fruiting bodies of $F$. fastuosus were brush cleaned, dried in the oven at $40{ }^{\circ} \mathrm{C}$ to a constant mass 
and pulverized. Shredded and ground mushroom materials of fruiting bodies from $F$. fastuosus $(1 \mathrm{~kg})$ were subjected to sonication extraction with methanol (4 L), for 5-6 $\mathrm{h}$ at room temperature. Methanol extract was filtered twice through Whatman No. 1 filter paper and same extraction procedure was repeated for the residue. Filtrates were combined and evaporated to dryness at $40{ }^{\circ} \mathrm{C}$ under reduced pressure using rotary evaporator to remove methanol. The resulting dried methanol extract was dissolved in distilled water $(500 \mathrm{~mL})$ and was partitioned in to hexane, dichloromethane and ethyl acetate (500 mL each), respectively. Ethyl acetate fraction of $F$. fastuosus was evaporated in a rotary evaporator to be used in subsequent fractionation and isolation of bioactive components.

\section{Fractionation, isolation and structure elucidation of the bioactive component}

Bioactivity guided isolation of active principles using chromatographic techniques

The dried ethyl acetate fraction of $F$. fastuosus was dissolved in a minimum amount of methanol and mixed with $5 \mathrm{~g}$ of silica gel (230-400 mesh, $60 \AA$ ). The resulting silica gel slurry was dried using rotary evaporator and placed at the top of $10 \mathrm{~mm}$ diameter column filled with silica gel to produce final bed height of $100 \mathrm{~mm}$. The column of silica was eluted, using a gradient solvent system starting from $100 \%$ hexane to $1: 1$ hexane: ethyl acetate $(100 \mathrm{~mL}$ each in $5 \%$ step gradient). Based on the bioactivity and TLC studies, the eluted fraction numbers 30-34 using 70: 30 hexane: ethyl acetate solvent system were preferred for further isolation and purification of active compound.

The combined fraction numbers 30-34 were concentrated to dryness at reduced pressure. Resulting residue was dissolved in methanol and mixed with silica gel as mentioned previously. Subsequently, the gel slurry was introduced to a similar size $(10 \mathrm{~mm}$ diameter; final bed height of $100 \mathrm{~mm}$ ) of normal phase silica column packed with silica. The column of silica was eluted using a gradient solvent system starting from 100\% hexane to $75: 25$ hexane: ethyl acetate solvent system (1\% step gradient). Based on the bioactivity and TLC studies, the eluted fractions number 21-25 using 91: 9 hexane: ethyl acetate solvent system were subjected to preparative thin-layer chromatography (developed twice with hexane/ethyl acetate, 9:1). Subsequently, it resulted in $15 \mathrm{mg}$ of a white solid, which proved to be nearly pure by TLC analysis where compound was dissolved in $\mathrm{CH}_{3} \mathrm{OH}$ and spotted on normal phase TLC plates using pet. ether/ ethyl acetate (3:1) mixture to give a consolidated under $254 \mathrm{~nm}$ UV lamp. Final purification of the compound was achieved by recrystallization from methanol.
Identification and characterization of the compounds by nuclear magnetic resonance (NMR) and mass spectrometry (MS)

One and two dimensional NMR spectra, including ${ }^{1} \mathrm{H}$ NMR, ${ }^{13} \mathrm{C}$ NMR, DEPT ${ }^{13} \mathrm{C}$ NMR, COSY, HMQC, HMBC and NOESY were recorded to obtain chemical shift information of the active compound using $\mathrm{CD}_{3} \mathrm{OD}$ as the solvent. Electrospray Ionization Mass Spectrometry (EIMS) was performed to obtain the high resolution mass spectrum.

\section{Cell lines and cell culture}

The RD, HepG-2 and CC-1 cell lines were used in the determination of in vitro cytotoxicity of isolated compound. Human muscle rhabdomyosarcoma (RD) and Rat liver normal (CC-1) cell lines were obtained from Medical Research Institute, Colombo 08. Human hepato cellular carcinoma (HepG-2) cell line was obtained from Dr. Panjwani Center for Molecular Medicine and Drug Research, International Center for Chemical and Biological Sciences, University of Karachi. The cells were cultured and preserved in the Department of Biochemistry and Molecular Biology until used them in cytotoxicity experiments. The cells were cultured in DMEM supplemented with $10 \%$ heat inactivated fetal bovine serum (FBS), HEPES, 3\% glutamine, sodium bicarbonate and antibiotic (penicillin/streptomycin). All the cultured cell lines were incubated at $37{ }^{\circ} \mathrm{C}$ in a humidified $\mathrm{CO}_{2}$ incubator.

\section{In vitro cytotoxicity and identification of the apoptotic features of treated cells with isolated compound from $F$. fastuosus}

MTT assay

The RD and Hep-G2 cells were seeded in 24-well plates at the density of $2 \times 10^{5}$ cells per well and CC- 1 cells were cultured at a density of $2 \times 10^{3}$ cells per well followed by incubation at $37{ }^{\circ} \mathrm{C}$ for overnight in a humidified $\mathrm{CO}_{2}$ incubator. Test compound was dissolved in methanol: DMSO (1:1) mixture and confluent monolayers were treated with different concentrations of the above prepared test solution followed by incubation at $37{ }^{\circ} \mathrm{C}$ for $24 \mathrm{~h}$. In all experiments, cycloheximide $(5 \mathrm{mM}, 50 \mu \mathrm{L})$ was used as the positive control and negative control contained the growth media and the solvent mixture used to dissolve the test compound. Subsequently, the cells treated with test solution were subjected to MTT cell viability assay. The culture medium was replaced with fresh growth medium $(1 \mathrm{~mL})$ and MTT $(5 \mathrm{mg} / \mathrm{mL} ; 100 \mu \mathrm{L})$ was added to each well. The cells were incubated at $37^{\circ} \mathrm{C}$ for $3 \mathrm{~h}$ and the growth medium was aspirated carefully. The remaining formazan crystals were solubilized in $750 \mu \mathrm{L}$ of $0.05 \mathrm{M} \mathrm{HCl}$ prepared in 2-propanol and absorbance was measured at 
$570 \mathrm{~nm}$. Percentage cell viability was determined using the formula: Percentage cell viability $=[$ (Absorbance of untreated cells -Absorbance of treated cells)/Absorbance of untreated cells]"100 (Additional file 1). The net absorbance from the wells of the negative control was considered as the $100 \%$ viability. $\mathrm{EC}_{50}$ values were determined by regression analysis $\left(R^{2}>0.95\right)$ of the corresponding dose response curves of percentage inhibition of cell viability and concentration of the test solution.

\section{Morphological determination}

The apoptotic morphological changes of treated cells with different concentrations of the test solution over $24 \mathrm{~h}$ were observed via microscopic examination of cells. Morphological changes were compared with negative and positive controls under the light microscope.

\section{Acridine orange-Ethidium bromide (AO/EB) staining}

Apoptotic morphology of treated cells was detected and distinguished by acridine orange-ethidium bromide (AO/EB) fluorescent staining. The staining method was performed via introducing a mixture of fluorescent dyes, acridine orange and ethidium bromide in 1:1 ratio on treated cells. RD, HepG- 2 cancer cells $\left(2 \times 10^{3}\right.$ cells/well $)$ and CC- 1 cells $\left(2 \times 10^{2}\right.$ cells/well $)$ were seeded in chamber slides. Resulting confluent layers were treated with different concentrations of the test solution and incubated at $37{ }^{\circ} \mathrm{C}$ for $24 \mathrm{~h}$. The adherent cells were washed with $200 \mu \mathrm{L}$ of PBS and $2 \mu \mathrm{L}$ of the dye mixture containing ethidium bromide $(100 \mathrm{mg} / \mathrm{mL})$ and acridine orange $(100 \mathrm{mg} / \mathrm{mL})$ in 1:1 ratio was placed on each well of the chamber slide. Chamber slides were examined immediately under the florescence microscope and images were captured.

\section{Calculations and statistics}

All experiments were performed in triplicate and values given are representative for at least three independent experiments. All the results of the experiments were expressed as the mean \pm standard deviation (Mean \pm SD). The results were statistically analyzed by $T$ test using Microsoft Excel. A $p$-value less than 0.05 were considered as statistically significant.

\section{Ethical approval}

The requirement for ethical approval was waived.

\section{Result}

Identification of compound isolated from the extract of $F$. fastuosus

Purified compound was obtained from the extract of Fulviformes fastuosus to yield $4 \mathrm{mg}$ of the compound as white colour needle shaped crystals. The EIMS showed molecular ion peak at $m / z$ 392. Its molecular formula,
$\mathrm{C}_{28} \mathrm{H}_{40} \mathrm{O}$ was determined by HREI MS which showed molecular ion peak $m / z$ at 392.3090 (calcd for $\mathrm{C}_{28} \mathrm{H}_{40} \mathrm{O}=$ 392.3079). The ${ }^{1} \mathrm{H}-\mathrm{NMR}$ spectrum (Table 1 ) displayed signals for six methyl groups at $\delta 0.83\left(3 \mathrm{H}, \mathrm{d}, J=7.5 \mathrm{~Hz}, \mathrm{H}_{3}-\right.$ 26), $0.85\left(3 \mathrm{H}, \mathrm{d}, J=7.5 \mathrm{~Hz}, \mathrm{H}_{3}-26\right), 1.03\left(3 \mathrm{H}, \mathrm{s}, \mathrm{H}_{3}-18\right)$, 1.06 (3H, s, $\left.\mathrm{H}_{3}-19\right), 1.07$ ( $\left.3 \mathrm{H}, \mathrm{d}, J=7.5 \mathrm{~Hz}, \mathrm{H}_{3}-21\right), 1.08$ $\left(3 \mathrm{H}, \mathrm{d}, J=7.5 \mathrm{~Hz}, \mathrm{H}_{3}-28\right)$. Additionally, the ${ }^{1} \mathrm{H}-\mathrm{NMR}$ spectrum displayed resonances for five downfield signals at $\delta 5.26 \mathrm{~m}(\mathrm{H}-22), 5.27 \mathrm{~m}(\mathrm{H}-23), 5.70 \mathrm{~s}(\mathrm{H}-4), 6.10 \mathrm{~d}$ $(J=9.6 \mathrm{~Hz}, \mathrm{H}-6), 6.71 \mathrm{~d}(J=9.6 \mathrm{~Hz}, \mathrm{H}-7)$. The structure of compound was further confirmed by 2D-NMR spectra (COSY, HSQC, HMBC, NOESY) (Additional file 2). The spectral data were in good agreement with those of ergosta-4,6,8 (14),22-tetraen-3-one which was previously reported by Youla et al., (1992) [24]. Hence, the interpretation of above spectral data (Table 1) resulted in the identification of the chemical structure of purified

Table $1{ }^{13} \mathrm{C}$-and ${ }^{1} \mathrm{H}-\mathrm{NMR}$ chemical shift values of ergone (ppm, $\mathrm{CD}_{3} \mathrm{OD}, 150$ and $600 \mathrm{MHz}$, respectively)

\begin{tabular}{|c|c|c|}
\hline C. No. & $\delta_{c}$ & $\delta_{H}(J, H z)$ \\
\hline 1 & 35.2 & - \\
\hline 2 & 34.8 & - \\
\hline 3 & 202.3 & - \\
\hline 4 & 123.2 & $5.70 \mathrm{~s}$ \\
\hline 5 & 167.9 & - \\
\hline 6 & 125.3 & $6.10 \mathrm{~d}(9.6)$ \\
\hline 7 & 136.7 & $6.71 \mathrm{~d}(9.6)$ \\
\hline 8 & 125.9 & - \\
\hline 9 & 45.7 & - \\
\hline 10 & 38.0 & - \\
\hline 11 & 20.0 & - \\
\hline 12 & 36.8 & - \\
\hline 13 & 45.2 & - \\
\hline 14 & 157.5 & - \\
\hline 15 & 26.2 & - \\
\hline 16 & 27.6 & - \\
\hline 17 & 57.2 & $1.29 \mathrm{~m}$ \\
\hline 18 & 16.9 & 1.03 \\
\hline 19 & 18.2 & 1.06 \\
\hline 20 & 40.6 & - \\
\hline 21 & 20.1 & 1.07 \\
\hline 22 & 133.7 & $5.26 \mathrm{~m}$ \\
\hline 23 & 130.8 & $5.27 \mathrm{~m}$ \\
\hline 24 & 44.4 & - \\
\hline 25 & 35.4 & 2.12 \\
\hline 26 & 20.5 & $0.83 d(7.5)$ \\
\hline 27 & 21.7 & $0.85 d(7.5)$ \\
\hline 28 & 20.4 & $1.08 \mathrm{~d}(6.4)$ \\
\hline
\end{tabular}


compound as ergosta-4,6,8 (14),22-tetraen-3-one or ergone (Fig. 1).

\section{In vitro Cytotoxicity of ergone}

As evident in Fig. 2a, ergone demonstrated a potent cytotoxic effect on RD cells with remarkably lower $\mathrm{IC}_{50}$ value of $1.49 \pm 2.74 \mathrm{mM}$. Moreover, Fig. 2a depicts a dose dependent increase of percentage inhibition of cell viability over a concentration range of $0.01-1.5 \mu \mathrm{g} / \mathrm{mL}$ of test solution. The maximum of $74 \%$ inhibition of cell growth was observed at $5.0 \mu \mathrm{g} / \mathrm{mL}$ of the test solution. Ergone also exhibited a strong cytotoxicity effect against HepG- 2 cells by showing an $\mathrm{IC}_{50}$ of $68.32 \pm 2.49 \mathrm{mM}$ in a dose dependent manner (Fig. 2b). Positive control (cycloheximide) exhibited $76.35 \pm 3.12 \%$ growth inhibition at the concentration $(5 \mathrm{mM}, 50 \mu \mathrm{L})$ used.

The $\mathrm{IC}_{50}$ value determined for the mean of the three independent sample preparations of ergone dissolved in methanol: DMSO (1:1) against normal mammalian cell line (CC-1) was $22.99 \pm 2.42 \mathrm{mM}$ (Fig. 2c). Thereby, selectivity index shown by the compound ergone against RD cells becomes 15.44 indicating less cytotoxic effect on normal cells according to the definition of Prayong et al., (2008) [25].

\section{Morphological changes}

The morphological changes observed on RD, HepG-2, and $\mathrm{CC}-1$ cells after the treatment with ergone are represented in Figs. 3, 4 and 5. The morphology of untreated cells and cells treated with the lower concentrations of ergone appeared in elongated shape. The cells treated with higher doses exhibited apoptotic features including cellular shrinkage, oval or irregular shape, fragmented nuclei, apoptotic bodies formation and condensed cytoplasm. The concentration of ergone in which cells started to display apoptotic features varied depending on the type of the cell line.

\section{Ethidium bromide/acridine orange staining}

As evident in Figs. 6, 7 and 8, the apoptotic morphology was detected by acridine orange-ethidium bromide $(\mathrm{AO} /$ EB) fluorescent staining of RD, HepG-2 and CC-1 cell lines treated with ergone.

As demonstrated in Figs. 6, 7 and 8, nuclei stained with green colour demonstrate live cells while greenish yellow shows early apoptotic cells. Condensed Orange red nuclei indicate late apoptotic cells whereas red colour exhibits dead cells. The untreated cells (negative control) and treated cells with the lower concentrations of the compounds appeared with the normal nuclei presented in bright green. Cells treated with higher doses of the compounds and $5 \mathrm{mM}$ concentration of positive control showed unique features of apoptosis such as chromatin condensation, nuclear fragmentation, presence of apoptotic bodies and blebbing formation, are of significance upon examination of stained cells with ethidium bromide/acridine orange. Chromatin condensation and nuclear fragmentation were predominantly observed apoptotic features for treated cells with high concentrations of the compounds. In addition, number of apoptotic cells was gradually increased with the treatment dose.

\section{Discussion}

The past decade has witnessed the overwhelming interest in isolation and characterization of bioactive compounds from medicinal mushrooms due to the fact that natural products of mushroom origin are found to possess a remarkably high pharmacological index $[26,27]$. The mounting evidences from various scientific studies regarding the applications of mushroom extracts and

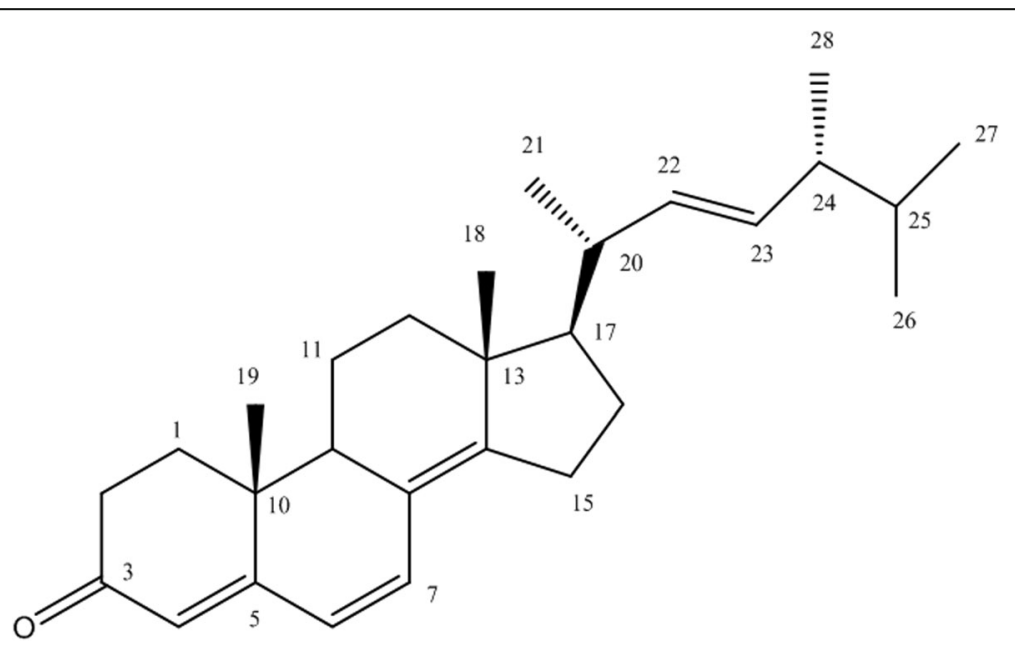

Fig. 1 Structural Formula of Ergone 

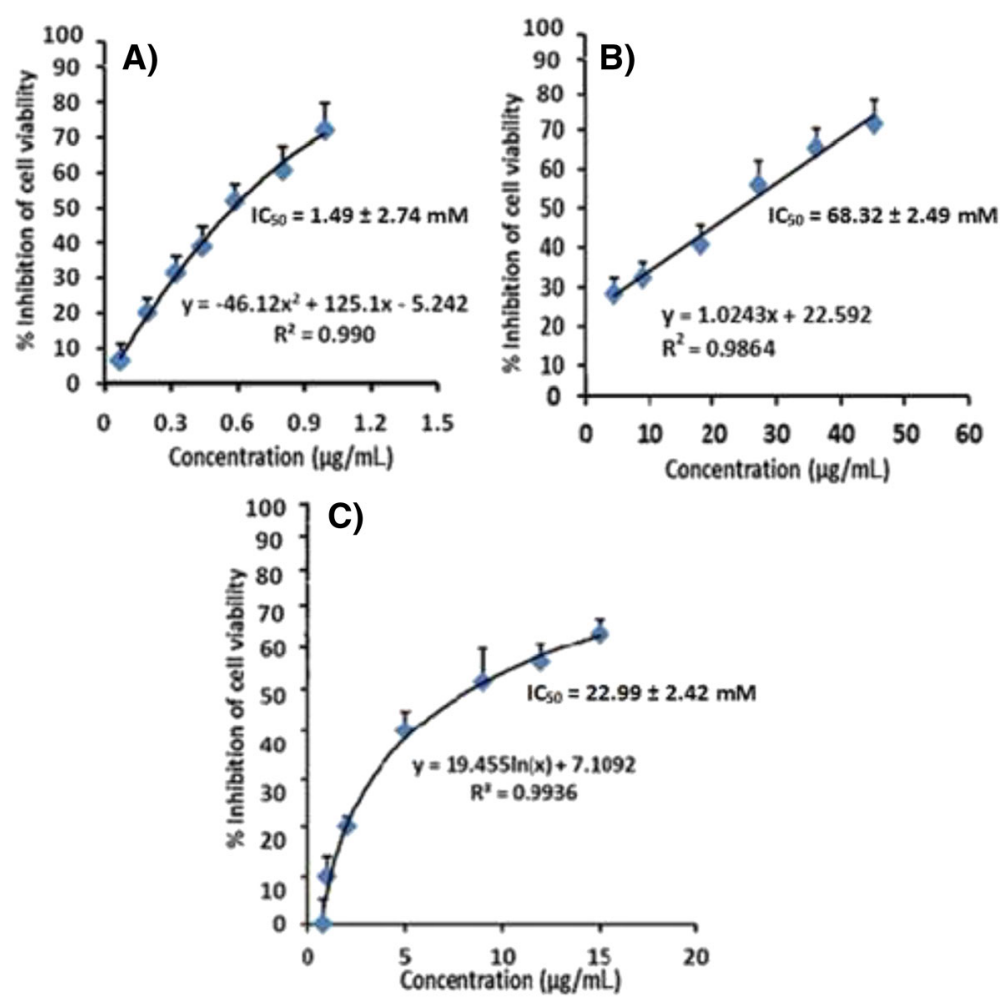

Fig. 2 The percentage inhibition of cell viability against (a) RD (b) Hep-G2 (c) CC-1 cell line as determined by MTT assay, after $24 \mathrm{~h}$ treatment with the ergone. The graphical data are represented as mean \pm SD of three independent experiments $(n=3)$
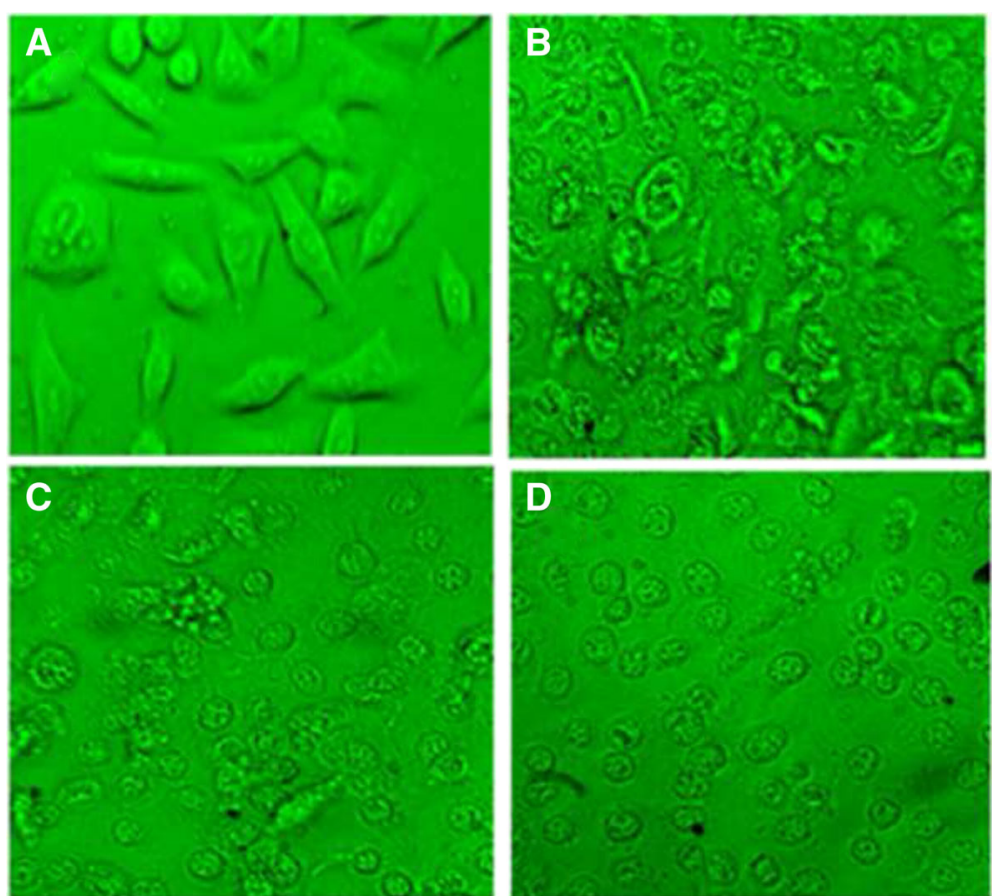

Fig. 3 Light micrographs of RD cell line after $24 \mathrm{~h}$ of incubation with ergone at different concentrations. a- $0.1 \mu \mathrm{M}$; (b)- $2 \mu \mathrm{M}$; (c)- $50 \mu \mathrm{M}$; (d)- Cycloheximide as the positive control $(5 \mathrm{mM} ; 50 \mu \mathrm{L})(\times 40)$ 

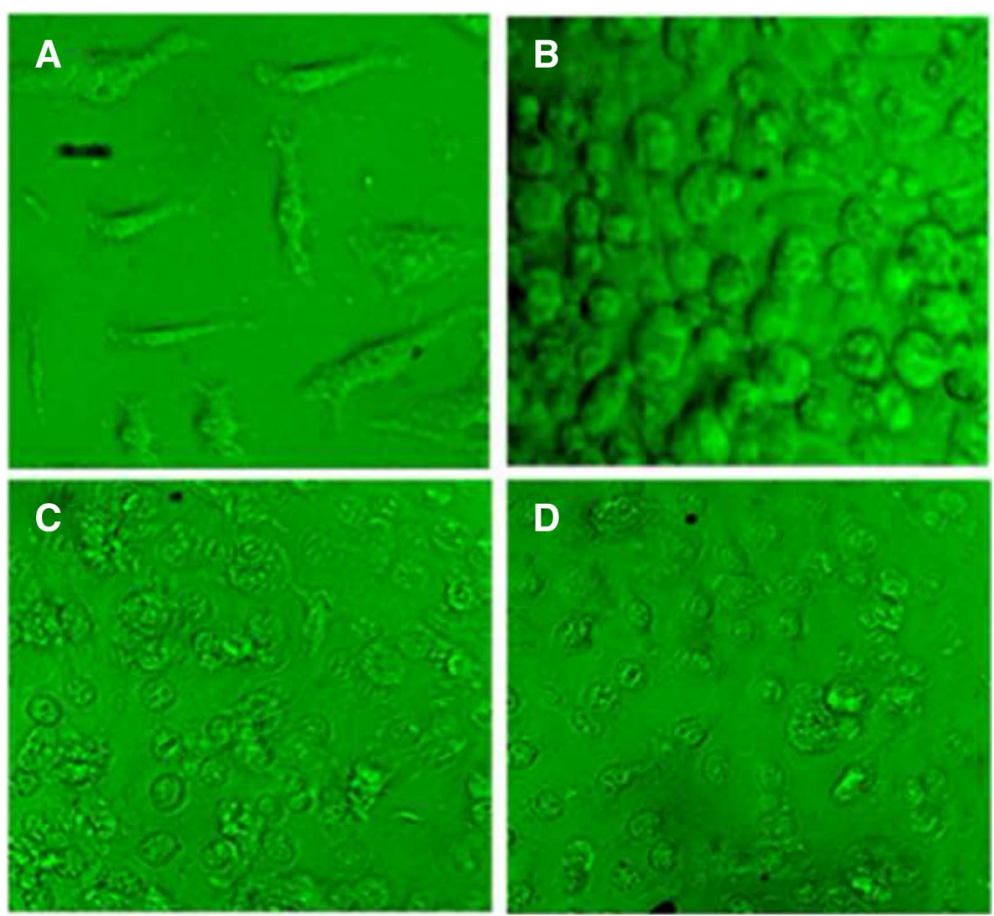

Fig. 4 Light micrographs of Hep-G2 cell line after 24 h of incubation with ergone at different concentrations. a- 5 mM; (b)- 50 mM; (c)- 80 mM; (d)- Cycloheximide as the positive control $(5 \mathrm{mM} ; 50 \mu \mathrm{L})(\times 40)$
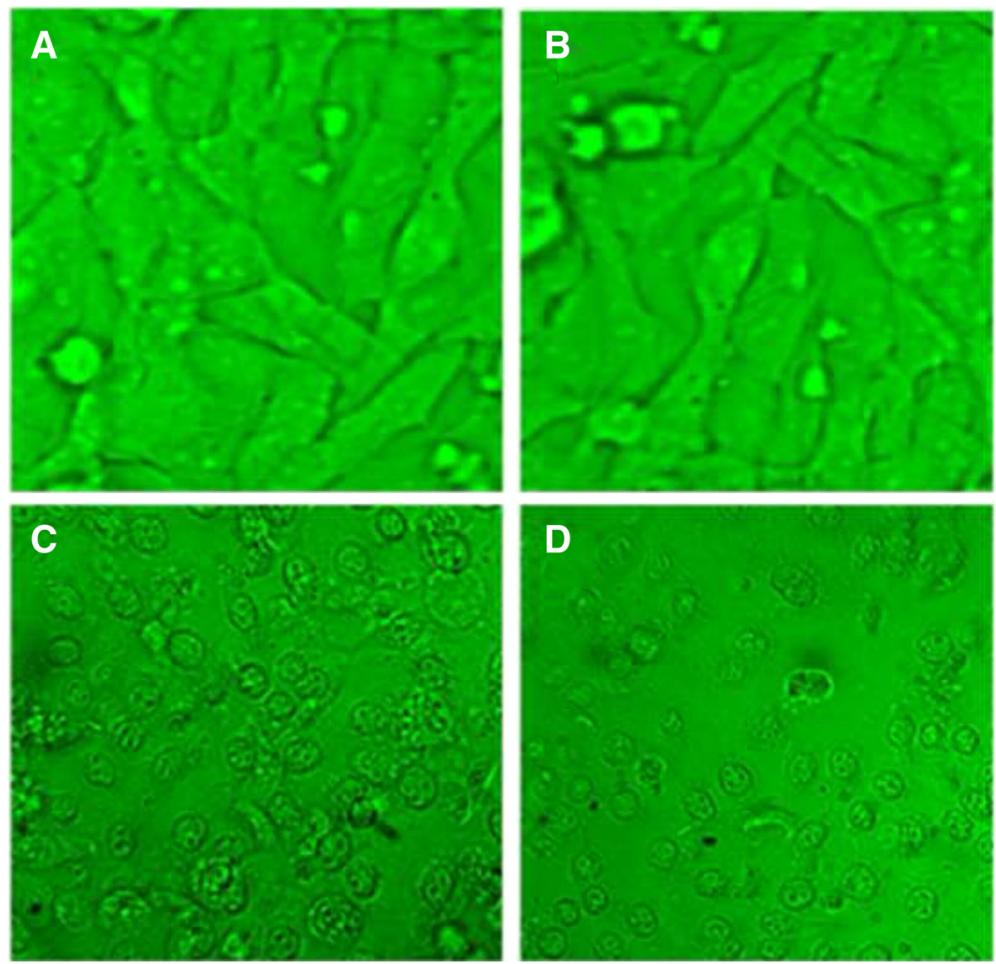

Fig. 5 Light micrographs of CC-1 cell line after 24 h of incubation with ergone at different concentrations. a- 2 mM; (b)- 10 mM; (c)- 40 mM; (d)- Cycloheximide as the positive control $(5 \mathrm{mM} ; 50 \mu \mathrm{L})(\times 40)$ 

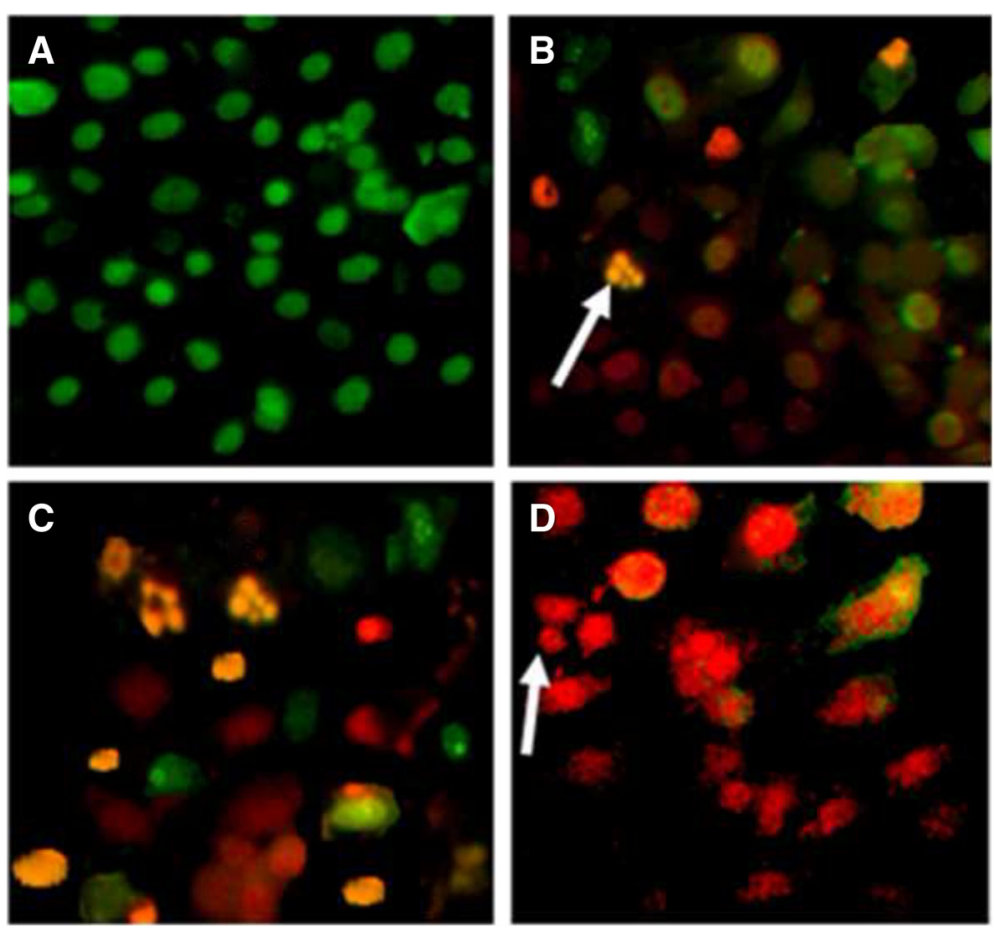

Fig. 6 Apoptotic morphology detection by acridine orange-ethidium bromide (AO/EB) fluorescent staining of RD cell line treated with ergone dissolved in methanol: DMSO (1:1). a- Negative control; (b)- $2 \mu \mathrm{M}$; (c)- $5 \mu \mathrm{M}$; (d)- Cycloheximide as the positive control (5 mM; $50 \mu \mathrm{L})(\times 40)$. Arrows indicate formation of apoptotic bodies
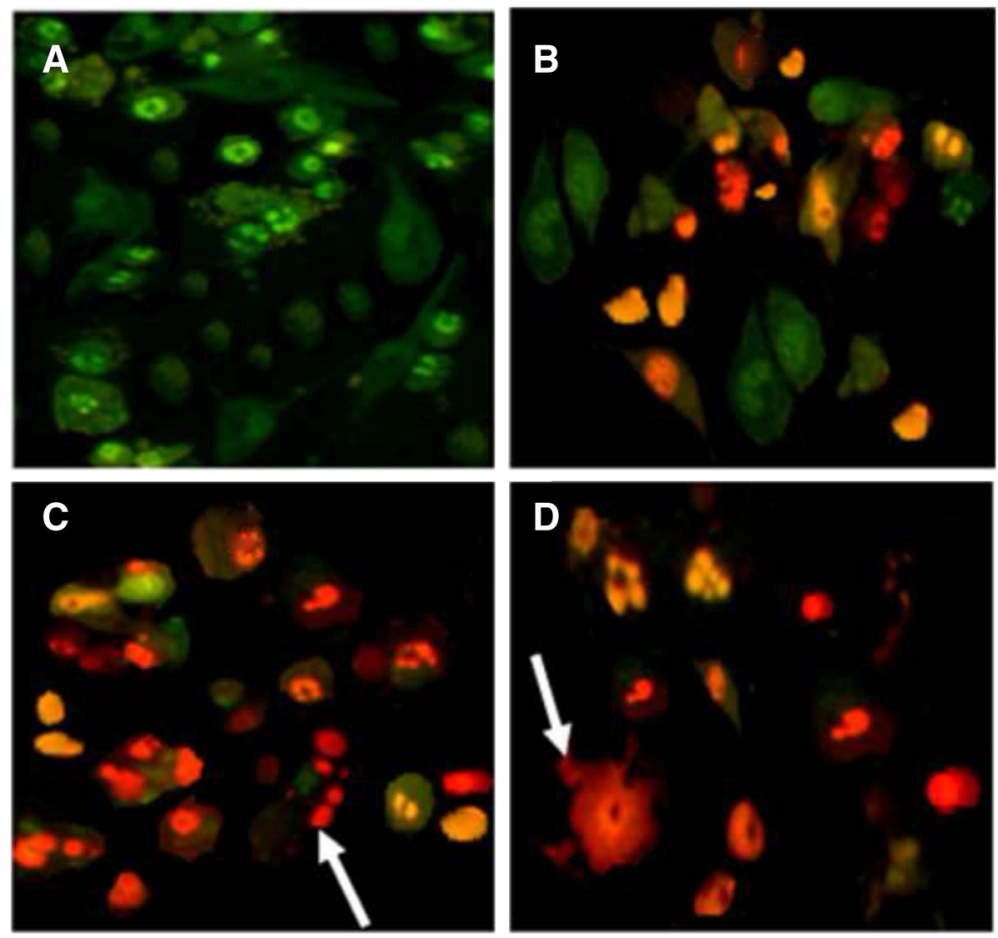

Fig. 7 Apoptotic morphology detection by acridine orange-ethidium bromide (AO/EB) fluorescent staining of HepG-2 cell line treated with ergone dissolved in Methanol: DMSO (1:1). a- Negative control; (b)- $80 \mu \mathrm{M}$; (c)- $130 \mu \mathrm{M}$; (d)- Cycloheximide as the positive control (5 mM; $50 \mu \mathrm{L})$ $(\times 40)$. Arrows indicate formation of apoptotic bodies 

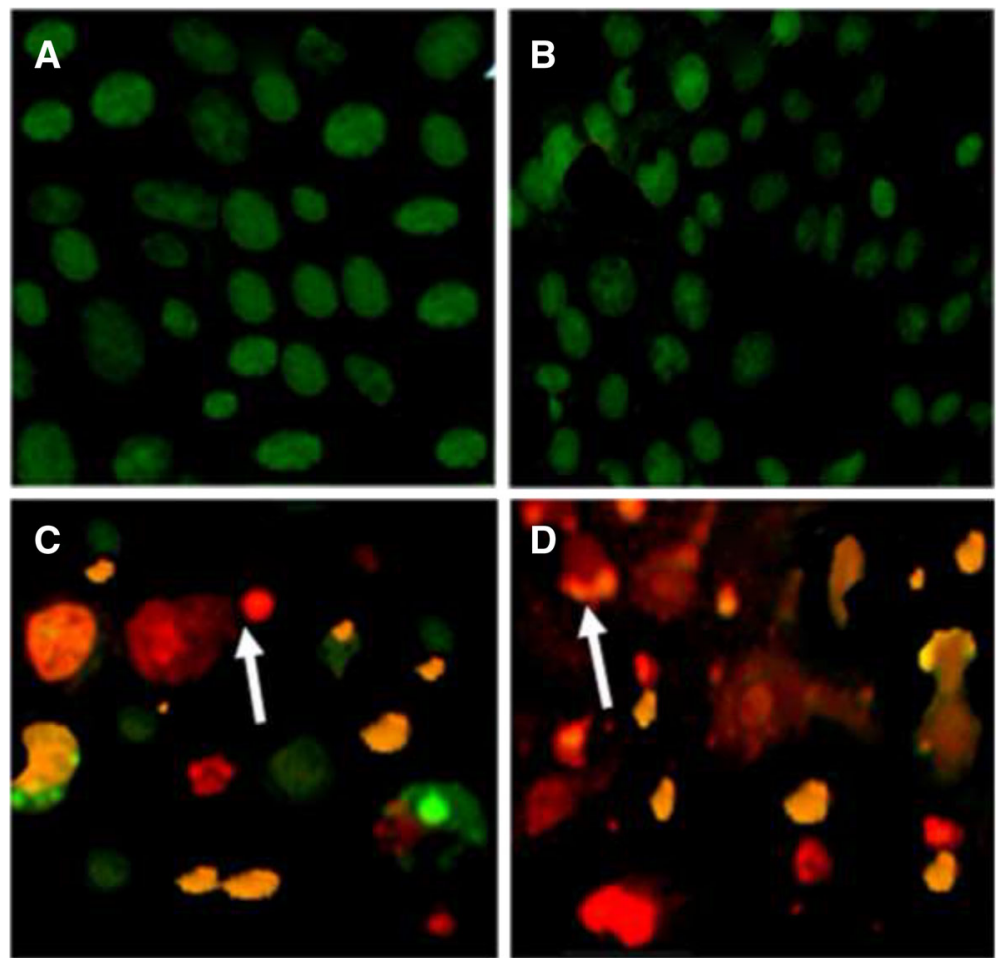

Fig. 8 Apoptotic morphology detection by acridine orange-ethidium bromide (AO/EB) fluorescent staining of CC-1 cell line treated with ergone dissolved in Methanol: DMSO (1:1). a- Negative control; (b)- $6 \mu \mathrm{M}$; (c)- $50 \mu \mathrm{M}$; (d)- Cycloheximide as the positive control (5 mM; $50 \mu \mathrm{L})$. This figure denotes the results of at least 3 independent experiments (Original magnification 40x). Arrows indicate formation of apoptotic bodies

substances in the development of anti-cancer therapeutics unarguably make it a fast-track research area worth mass attention. Consequently, mushroom consumption has been shown to prevent the development of cancer later in life with studies reporting an inverse correlation between mushroom intake and the risk of developing cancer $[28,29]$. In this perspective, the current study has been succeeded in the isolation of a potent cytotoxic compound namely ergone which is derived from a Sri Lankan mushroom. Ergone is an essential steroid, which belongs to ergosterol group [30]. Since it is necessary to expand the current extraction protocols with the increasing interest in mushroom metabolites, a novel and easy isolation method have been optimized in the current invention to isolate ergone with high reproducibility. Specifically, the extraction and isolation process of ergone is rapid, simple, inexpensive and comprehensive with respect to the constituents to be isolated.

In vitro cytotoxic activity of isolated product ergone against RD and HepG-2 cells were determined by MTT cell viability assay, which is a well-established colorimetric method to assess the cell proliferation and cell viability. It has been revealed that ergone isolated from $F$. fastuosus has promising cytotoxic properties against RD cells with less cytotoxicity effect on normal CC-1 cells $(\mathrm{SI}=15.44)$. Moreover, ergone also showed strong cytotoxic activity against HepG-2 cells being less toxic to normal CC-1 cells. However, cytotoxic activity of ergone against $\mathrm{RD}$ cell line is significantly high compared to HepG-2 cells $(p<0.05)$. The apoptotic features observed via microscopic examination of treated cells and $\mathrm{AO} / \mathrm{EB}$ fluorescent staining evidenced the apoptosis induced by ergone against RD and HepG-2 cells. Morphological characterization and ethidium bromide/acridine orange staining of treated cells revealed that the cell death induced by ergone has mediated through apoptosis. It strengthens the results obtained via MTT cell viability assay.

Our previous study has revealed that the crude methanolic extract of $F$. Fastuosus possess cytotoxic activity against RD cell line with an $\mathrm{IC}_{50}$ of $14.72 \pm 1.56 \mu \mathrm{g} / \mathrm{mL}$ [31]. Ergone's cytotoxic activity against RD cell line $(584.01 \pm 2.74 \mathrm{ng} / \mathrm{mL})$ has become twenty five times greater than the cytotoxic activity shown by the crude extract of $F$. fastuosus in terms of $\mathrm{IC}_{50}$ against $\mathrm{RD}$ cell line. Hence, it can be concluded that the promising cytotoxic activity of $F$. fastuosus could be largely contributed by the remarkably high cytotoxic activity of ergone. In addition, mangiferin, a strong anticancer compound isolated from Mangifera indica has shown an inhibitory concentration $\left(\mathrm{IC}_{50}\right)$ of $33.40 \mu \mathrm{g} / \mathrm{mL}$ against $\mathrm{RD}$ cells [32]. Interestingly, antiproliferative activity shown by 
ergone was found to be significantly greater $(p<0.05)$ than the anticancer activity of mangiferin. Importantly, the present discovery has become the first study of isolating ergone from $F$. fastuosus and it is appeared to be an essential anti-tumor drug lead against rhabdomyosarcoma. Currently, the treatment regime of rhabdomyosarcoma comprises of chemotherapy and radiation along with surgery while producing adverse side effects including neurotoxicity, hepatotoxicity and cardiotoxicity [33]. Hence, the use of afore kind of natural products against $\mathrm{RD}$ is an extremely promising strategy for remedy of rhabdomyosarcoma. Intriguingly, most of the mushrooms belong to the family of Hymenochaetaceae have long been used as edible forms [34]. Therefore, ergone, which is isolated from family Hymenochaetaceae, has a greater potential to act safely in human body without creating any complications. In addition, this fact was supported by the high selectivity index shown by the ergone against RD sarcoma cells.

\section{Conclusion}

Ergone is a potent cytotoxic compound against RD and HepG-2 cancer cell lines being less toxic to normal CC1 cells. Moreover, ergone has shown significantly greater cytotoxic activity against $\mathrm{RD}$ cell line compared to HepG-2 cell line. The present findings imply the propensity of ergone to develop as a safe pharmaceutical composition against rhabdomyosarcoma with a high efficacy for inducing cell death of RD while being less toxic to normal cells. Intriguingly, above discovery provides a scientific proof of the traditional awareness in using natural compounds isolated from medicinal mushrooms as anticancer agents.

\section{Additional files}

Additional file 1: A summary of the data obtained from MTT assay. (XLSX $10 \mathrm{~kb}$ )

Additional file 2: 1D, 2D and mass spectra. (DOCX $12600 \mathrm{~kb}$ )

\begin{abstract}
Abbreviations
${ }^{13}$ C NMR: Carbon nuclear magnetic resonance spectroscopy; ${ }^{1} \mathrm{H}$ NMR: Proton nuclear magnetic resonance spectroscopy; AO/EB: Acridine orange $(\mathrm{AO})$ /ethidium bromide $(\mathrm{EB}) ; \mathrm{CD}_{3} \mathrm{OD}$ : Deuterated methanol; $\mathrm{CH}_{3} \mathrm{OH}$ : Methanol; COSY: $\mathrm{H}-\mathrm{H}$ correlation spectroscopy; DEPT ${ }^{13} \mathrm{C}$ NMR: Distortionless enhancement polarization transfer carbon nuclear magnetic resonance spectroscopy; DMSO: Dimethyl sulfoxide; EIMS: Electrospray ionization mass spectrometry; $\mathrm{HCl}$ : Hydrochloric acid; HMBC: Heteronuclear multiple-bond correlation spectroscopy; HMQC: Heteronuclear multiple-quantum correlation spectroscopy; MTT: 34 , 5-(dimethylthiazol-2-yl) 2-5-diphenyl tetrazolium bromide; NMR: Nuclear magnetic resonance; NOESY: Nuclear Overhauser effect spectroscopy; SI: Selectivity index; TLC: Thin layer chromatography
\end{abstract}

\section{Acknowledgement}

The authors express special gratitude to Prof. Iqbal Choudhary, Senior Professor, HEJ Research Institute, ICCBS, and University of Karachi for providing facilities in carrying out the chemistry aspects of this research at
HEJ research Institute and supporting in every aspect of the study. The authors are grateful to Ms. S. Ediriweera and Mr. N. Gunasekara in identification of the specimens, helping with the sample collection and solvent extraction. Authors express special gratitude to Mr. Kanishka Senathilake, IBMBB, University of Colombo for the immense support given throughout this work. Authors convey sincere gratitude to Dr. Sunethra Gunasena, Dr. Omala Wimalaratne and Mrs. Devika, Medical Research Institute, Colombo 08 for providing required cell lines. The authors are also thankful to Mrs. Pavithra and staff members of the Department of Wildlife Conversation for issuing the necessary permits to carry out this study.

\section{Funding}

This work was financially supported by the National Research Council of Sri Lanka (Grant no. 11-40).

\section{Authors' contributions}

DF performed all the experiments, data analysis and drafted the manuscript. AA performed structure elucidation, supervision and drafted the manuscript. PS designed, analyzed and supervised the study. RW designed and supervised the study. DdS and CN supervised and designed the study. All authors read and approved the final manuscript.

\section{Competing interests}

The authors declare that they have no competing interests.

\section{Consent for publication}

Not applicable.

\section{Ethics approval and consent to participate}

Not applicable.

\section{Author details}

${ }^{1}$ Department of Plant Sciences, Faculty of Science, University of Colombo, Colombo 03, Sri Lanka. ²Department of Molecular Biology and Biochemistry, Faculty of Medicine, University of Colombo, Colombo 03, Sri Lanka. ${ }^{3}$ Department of Chemistry, Faculty of Science, University of Colombo, Colombo 03, Sri Lanka. ${ }^{4}$ The Hussain Ebrahim Jamal Research Institute of Chemistry, ICCBS, University of Karachi, Karachi, Pakistan.

Received: 29 April 2016 Accepted: 18 November 2016

Published online: 25 November 2016

\section{References}

1. Keles A, Koca I, Gençcelep H. Antioxidant properties of wild edible mushrooms. J Food Process Technol. 2011;2:1-6.

2. Wang DH, Weng XC. Antitumor activity of extracts of Ganoderma lucidum and their protective effects on damaged HL-7702 cells induced by radiotherapy and chemotherapy. Zhongguo Zhong Yao Za Zhi. 2006;31(19): $1618-22$.

3. World Cancer Report - 2014. World Health Organization. 2014; pp. Chapter 1.1. ISBN 9283204298.

4. Compton MM. A biochemical hallmark of apoptosis: internucleosomal degradation of the genome. Cancer Metastasis Rev. 1992;11:105-9.

5. Bhanot A, Sharma R, Noolvi MN. Natural sources as potential anti-cancer agents: a review. J Phytomed. 2011;3:09-26.

6. Wasser SP. Review of medicinal mushrooms advances: good news from Old AlliesHerbalGram. American Bot Council. 2002;56:28-33.

7. Lindequist $U$, Niedermeyer THJ, Julich $W$. The pharmacological potential of mushrooms. Ecam. 2005;2(3):285-99.

8. Poucheret P, Fons F, Rapior S. Biological and pharmacological activity of higher fungi: 20-Year retrospective analysis. Mycologie. 2006;27:311-33.

9. Rai M, Tidke G, Wasser SP. Therapeutic potential of mushrooms. Nat Prod Rad. 2005;4(4):246-57.

10. Wasser SP, Weis AL. Medicinal propreties of substances occurring in higher basidiomycetes mushrooms: current perspectives. J Med Mushrooms. 1999; $1: 31-62$.

11. Lucas EH, Byerrum M, Clarke DA, Reilly HC, Stevens JA, Stock CC. Production of oncostatic principles in vivo and in vitro by species of the genus Calvatia. Antibiot Annu. 1958;6:493-6. 
12. Mizuno T. The extraction and development of antitumor active polysaccharides from medicinal mushrooms in Japan-Review. Inter J Medicinal Mushrooms. 1999;1:9-30.

13. Huang Z. Peoples Republic of China. Novel antitumor pharmaceutical composition comprising traditional Chinese medicine extracts. 2007; China patent CN 101049336.

14. Baskar R, Lavanya R, Mayilvizhi S, Rajasekaran P. Free radical scavenging activity of antitumour polysaccharide fractions isolated from Ganoderma lucidum (Fr.) P. karst. J Natur Prod Radiance. 2008;7(4):320-5.

15. Liu J, Wu Y, Kan J, Wang Y, Jin C. Changes in reactive oxygen species production and antioxidant enzyme activity of Agaricus bisporus harvested at different stages of maturity. J Sci Food Agric. 2013;93:2201-6.

16. Karunarathna SC, Udayanga D, Maharachchikumbura SN, Pilkington M, Manamgoda DS, Wijayawardene DNN, Ariyawansa HA, Bandara AR, Chukeatirote E, McKenzie EHC, Hyde KD. Current status of knowledge of Sri Lankan mycota. Curr Res Environ Appl Mycol. 2012;2(1):18-29.

17. Kannangara BTSDP, Paranagama PA, Rajapaksha RSCG. Endolichenic fungi diversity in different ecosystems of Sri Lanka, Proceedings of national mini symposium on bioindicators of environment health and biodiversity indices, The Sri Lanka Association for the advancement of Science and the Biodiversity secretariate of the ministry of environment, $21^{\text {st }}$ December, 2011; 71-78.

18. Fernando MDM, Wijesundera RLC, Soysa SSBDP, de Silva ED, Nanayakkara CM. In vitro cytotoxicity and antioxidant activity of the Sri Lankan Basidiomycete, Anthracophyllum lateritium. BMC Complement Altern Med. 2015;15:398-407. doi:10.1186/s12906-015-0924-9.

19. Abeywickrama BA. Diversity and endemism and the need for conservinrepresentative areas within national boundaries. Proceedings of a regional workshop on ecology and conservation of tropical humid forests of the Indomalayan Realm. Natural Resources, Energy and Science Authority, Colombo. 1987.

20. Nahata A. Ganoderma lucidum: a potent medicinal mushroom with numerous health benefits. Pharmaceut Anal Acta. 2013:4(10):1000e159.

21. Ghisalberti EL. Detection and Isolation of Bioactive Natural Products, in Bioactive Natural Products: Detection, Isolation and Structural Determination (Colegate, S. M. and Molyneux, R. J, eds.), CRC, Boca Raton, FL. 1993.

22. Stitcher O. New natura products and plant drugs with pharmacological. In: Wagner $\mathrm{H}$, Wolff $\mathrm{P}$, editors. Biological or therapeutic activity. New York Springer-Varlag; 1989.

23. Samarakoon KW, Lee JH, Dilip De Silva E, Kim UA, Wijesundara RLC, Lakmal $H H C$, Jeon YJ. Bioactivity evaluation of organic solvent extractions of Ganoderma lucidum: a Sri Lankan Basidiomycete. J NSF. 2013;41(3):249-57.

24. Youla ST, Patricia LF, James FB, David NH, Kelvin KO. Approaches towards the synthesis of a sulfur analog of ergosterol peroxide. Can J Chem. 1992; 70:158-63.

25. Prayong P, Barusrux S, Weerapreeyakul N. Cytotoxic activity screening of some indigenous Thai plants. Fitoterapia. 2008;79:598-601.

26. Cosa P, Vlietinck AJ, Berghe DV, Maes L. Anti-infective potential of natural products: How to develop a stronger in vitro 'proof-of-concept'. J Ethnopharmacol. 2006;106:290-302.

27. Menikpurage IP, Soysa SSSBDP, Abeytunga DTU. Antioxidant activity and cytotoxicity of the edible mushroom, Pleurotus cystidiosus against Hep-2 carcinoma cells. J NSF. 2012;40(2):107-14.

28. Barros L, Falcão S, Baptista P, Freire C, Vilas-Boas M, Ferreira ICFR. Antioxidant activity of Agaricus sp. mushrooms by chemical, biochemical and electrochemical assays. J Food Chem. 2008;111:61-6.

29. Oyetayo FL, Akindahunsi AA, Oyetayo VO. Chemical profile and amino acids composition of edible mushrooms Pleurotus sajor-caju. Nutr Health. 2007;18: 383-9.

30. Quanga DN, Bacha DD, Asakawab Y. Sterols from a Vietnamese WoodRotting Phellinus sp. Z Naturforsch. 2007;62b:289-92.

31. Fernando MDM, Wijesundera RLC, Soysa SSBDP, de Silva ED, Nanayakkara CM. In vitro antiproliferative activity of the Sri Lankan mushroom Fulviformes fastuosus. National Conference on Indigenous Systems of Medicine. 2015; pp 8.

32. Padma W, Kalaiselvia P, Yuvarajb R, Rabeeth M. Mangiferin induces cell death against rhabdomyosarcoma through sustained oxidative stress. Integr Med Res. 2015;4(2):66-75.

33. Torti FM, Bristow MM, Lum BL, Carter SK, Howes AE, Aston DA, et al. Cardiotoxicity of epirubicin and doxorubicin: assessment by endomyocardial biopsy. Cancer Res. 1986;46:3722-7.

34. Singh AK, Dikshit A, Sharma ML, Dixit SN. Fungitoxic activity of some essential oil. Econ Bot. 1980;34:186-90.

\section{Submit your next manuscript to BioMed Central and we will help you at every step:}

- We accept pre-submission inquiries

- Our selector tool helps you to find the most relevant journal

- We provide round the clock customer support

- Convenient online submission

- Thorough peer review

- Inclusion in PubMed and all major indexing services

- Maximum visibility for your research

Submit your manuscript at www.biomedcentral.com/submit
Biomed Central 